\author{
Arnold McMillin \\ Uniwersytet Londyński (Wielka Brytania) \\ University College London (UK) \\ e-mail: a.mcmillin@ucl.ac.uk
}

\title{
The Heritage of Janka Bryĺ: Lyrical Miniatures by Young Belarusian Writers
}

Спадчына Янкі Брыля: лірычныя мініяцюры маладых беларускіх пісьменнікаў

Spuścizna Janki Bryla: liryczne miniatury młodych pisarzy białoruskich

$\mathrm{T}$

The greatest prose writer and poet of the second half of the $20^{\text {th }}$ century, Vasil Bykaŭ (1924-2003) and Ryhor Baradulin (1935-2014), although still rightly revered for their honesty and inventiveness, do not appear to have many literary followers in any perceptible way. The same, however, cannot be said of their near-contemporary Janka Bryí (1917-2006) who, despite not being particularly well remembered by many of those who studied some of his works at school, nonetheless seems to have many followers or, at least, people who attempt the genre for which he was most famous: lyrical miniatures. This article attempts to consider the use of miniatures by representatives of the youngest generation of Belarusian writers, particularly those who made their literary debuts in poetry rather than prose (particularly those studied in Arnold McMillin: 2015), and writers in the journal "Maladość" at the turn of the century, who seem particularly attracted to what they often refer to as abrazki and minijaciury or even mini-proza and zamalioŭki. Naturally, these two cohorts offer a representative but not comprehensive view of this phenomenon.

The role of lyricism and miniatures in Belarusian literature of the $20^{\text {th }}$ century has been well studied by Mikola Miščančuk (2007) and Tacciana Dasajeva (2001), but most thorough is an excellent book by Hanna Kiślicyna (2000), which pays particular attention to lyrical miniatures in the work of Lieanid Halubovič (b. 1950) (Halubovič, 1998), Siarhej Dubaviec (b. 1959) (Dubaviec, 1992), Aleś Razanaŭ (b. 1947) (Razanaŭ, 1995) and above all Janka Bryĺ, also considering earlier writers like Źmitrok Biadulia (1913) and Maksim Harecki (1893-1936) (Harecki, 1993). The present article is based on Kiślicyna's principles as expressed in her monograph and also, less directly, the example of Sakrat Janovič (1936-2013), the outstanding Belarusian prose writer of eastern Poland (see, for example: Janovič, 1984). The thematic range 
of miniatures by young writers is in most cases very different from, for instance, those of Bryĺ, ranging from religion, pictures of nature (frequently personified), general philosophical themes, often with a strong personal angle, to, at one extreme, generations of mobile phones.

The concept of miniatures is somewhat loose. Kiślicyna's book firmly distinguishes lyrical miniatures from lyrical prose in general $(2000$, p. 8$)$, tracing her genre from the far older one of essay writing (2000, pp. 12-27); she also considers various other forms of short prose. Janovič's works, however, although not mentioned in her book, are quite close to her view of the genre, although they are not all short, and some are far from the philosophical element she regards as essential.

The examples of young writers that follow are variegated in form and content, something that reflects the wide range of creative writing in Belarus today, as the present writer discovered when trying to order some two score diverse young poets into eight chapters of a book (McMillin, 2015).

A number of young writers, particularly Maryja Martysievič (b. 1982) and Ihar Kulikoŭ (b. 1988), produce short prose in a form that resembles essays rather than lyrical miniatures: Martysievič is a very humorous writer, whose first book, Cmoki liatuć na nierast (Serpents will fly to spawn, 2008) has the subtitle 'Ese ŭ vieršach i prozie' (Essays in verse and prose); she is the author of various linked essays or sketches including, for example, 'Chadziem sa mnoj: vademecum pa horadzie Miensku' (Walk with me: a vademecum around the city of Minsk), 'Častka i celaje: rasčlianionka ciela kultury (A part and the whole: a dissection of the body of culture), and 'Pamiežnyja historyi' (Border tales) (Martysievič, 2008); also may be mentioned is her 'dziońnik' (diary), 'Palieskaja chronika (Palessian chronicle) (Martysievič, 2008, pp. 69-87). Kulikoŭ in his first book, Pavarot na mora (A turn to the sea, 2011), describes many real and imaginary travels, one example being a sequence of prose poems beginning 'My mahli b paznajomicca z taboju ŭ Flarencyi...' (We could have met in Florence...) (Kulikoŭ, 2011, pp. 75-85). Many of Kulikoŭ's works could be described as prose in verse or verse in prose, and two examples of them will be mentioned later. Other writers with prose set out in stanzas or verse without any formal sign, include Siarhiej Prylucki, whose Dzievianostyja forever (The nineties forever, 2008), consists of humorous, cynical and often angrily violent works that seem distant from lyricism of any kind. Adam Šostak (b. 1982) describes two pieces in his first book, Spatkańnie, Nie (A meeting? No, 2006) as poems in prose and they too will be considered later.

Źmicier Bajarovič (b. 1990) calls his first book, Šali (Scales, 2012), 'Liryčnaja-pobytavaja proza' (Lyrical everyday prose). In a perceptive introduction by fellow-poet Arciom Kavaleŭski (b. 1979), 'Kaliejdaskopna-vitražnaja proza Źmitra Bajaroviča' (The kaleidoscopic stained-glass prose of Źmicier Bajarovič) compares the images of his prose to those of Biadulia, Harecki, Bryĺ, Razanaŭ and others (Bajarovič, 2012, p. 5). The title poem Šali (2011-2012) suggests that all life is built on contrasts and contradictions; here the philosophical element is far stronger than any obvious lyricism: 
Шалі

Так атрымоўваецца, што нашае жыццё пабудавана на процілегласцях:

Каб цябе пачулі - трэба гаварыць шэптам. Тое, што ты аддаеш - вяртаецца. I робіцца тваім назаўжды. Тое, што ты думаеш пра іншых, не думаюць іншыя пра цябе. Самы блізкі чалавек - самы далёкі. Велькая дабрыня - гэта велькае зло. Велькая дабрыня гэта велькая злосць (толькі для розных людзей па-рознаму).

Самы шчыры смех - да слёз.

Падлога - столь.

Не - так.

Я - ты.

А паміж усім - шалі (Bajarovič, 2012, p. 11).

The theme of Jadnannie (Unity, 2011) is not entirely dissimilar, although this miniature begins not with a philosophical statement, but with a description of torrential rain, and it is the sight of a girl on tiptoe striving not to spill a glass of hot tea that leads to the conclusion in the last sentence: 'I чамусьці здаецца, што ў гэтым свеце ўжо ніколі не будзе яднання' (Bajarovič, 2012, p. 14).

In Chluśnia (Lying, 2010) Bajarovič describes how people deny even quite innocuous actions, concluding with another broad sentiment: 'Калі б не было хлусні, не было б сапраўдных людзей’ (Bajarovič, 2012, p. 33).

Humour plays a part in the last work to be mentioned, Cyrulnia (The barber's, 2011), where the first sentence is more serious than what follows:

\section{Цырульня}

Я знайшоў Атман у цырульні. У тытунёвых жаночых пальцах. У іх вандраванні па маёй галаве: прыкладна 3 чуба да макаўкі - моц, патыліца - прымус, акантоўка заахвочванне, з мочак вушэй да скроняў - адразу безвыходна маніпуляцыя.

Улада нада мной - нада мной. Валасы ж, дурні, кожны дзень растуць (Bajarovič, 2012, p. 28).

Another talented prose writer, who is also a poet and bard, Aleś Jemial'janaŭ-Šylovič (b. 1987) (Jemial'janaŭ-Šylovič, 2013; see also: McMillin, 2015, pp. 18-22) published in 2014 a cycle of prose miniatures under the title Teliepaetyka (Telepoetics) with the subtitle, Rytaryčnyja adkazy (Rhetorical responses) (Jemial'janaŭ-Šylovič, 2014). Three of them will serve as examples of his work in this genre: Pamiž (Between), Iścina (Truth) and Svaboda (Freedom). The first links natural phenomena to personal feelings and self-awareness: 
Паміж

Восеньскае сонца самае гарачае і небяспечнае. Ягоныя халодныя промні, што ледзь кранаюць паверхню сваім святлом, выпальваюць знутры. Так і абыякавасць чалавека, якога кахаеш, немагчыма трываць. Лепей ужо самае гарачае ліпеньскае надвор'е з задухаю і брыдкім ліпкім потам на ілбе і грудзях. Знаходжуся паміх апякаючай зоркай надзеі і ганарыста-халоднай зоркай зняверанасці (Jemial'janaŭ-Šylovič, 2014, p. 58).

Iścina is a humorous miniature about the fluidity of reality, particularly in connection with alcohol (although the latter is described realistically), at the centre of which is a strange bus ride with two notable Belarusian cultural figures:

Ісціна

Сёння зразумеў, што ісціна не ў віне - маёй ці тваёй - не вінаваты ніхто, тым больш віно. Мацней за віно п'яняць вочы маладой кабеты і бярозавы сок. Наконт першага едучы з Наталкай Кучмель і Віктарам Слінкам у аўтобусе, заўважыў вочы кандуктаркі і патануў без шанцу на ратаванне і асабліва не спрачаючыся са стыхіяй: $<$ У Вас вочы, як у німфы>, - яна ўсміхнулася і запыталася: $<$ А хто гэта?> - <Русалка $>-$ адказаў я. $-<$ Ваш квіток.>

Бярозавы сок можа ператварыцца ў гарэлку. Гэтаму цуду мяне навучыў Віця. Галоўнае, ўявіць, што п'еш не бярозавы сок, а гарэлку. Паспрабуйце - сапраўды хмяліць (Jemial'janaŭ-Šylovič, 2014, p. 58).

The title of the last miniature in this cycle, Svaboda (Freedom) is one that is often used passionately by young writers in the authoritarian society of Belarus. The first sentence is philosophically unexceptionable, but Jemial'janaŭ-Šylovič goes on to associate it with personal stability, family and hearth, as we read in the last lines:

Свабода - элементарнае (ня)веданне таго, што ты несвабодны.

$[\ldots]$

Магчыма, я атаясамліваю свабоду са стабільнасцю, хай бы й так. Стабільнасць з'яўляецца тады, калі ёсць што губляць. I Свабода там недалёка. Мая Свабода там, дзе ты... (Jemial'janaŭ-Šylovič, 2014, p. 62).

The already mentioned short prose pieces set out as verse by Kulikoŭ include several that relate, in concise and intermittently lyrical form, the stories of human lives, beginning with setting out into the world and often ending badly: typical is $J a$ vypraviǔsia z doma, niavyspany i biaśsiĺny što-kolviek pradbačyć... (I set out from 
home sleepless and without strength in order to foresee something...), which begins in a maternity home and ends, after many miseries, with death. Also worth mentioning is 'adnojčy ty pračnieśsia čalaviekam...' (one day you will wake up as a person...), a formless poem, which begins with feelings of rootlessness and oppression and ends very memorably in catastrophic collapse:

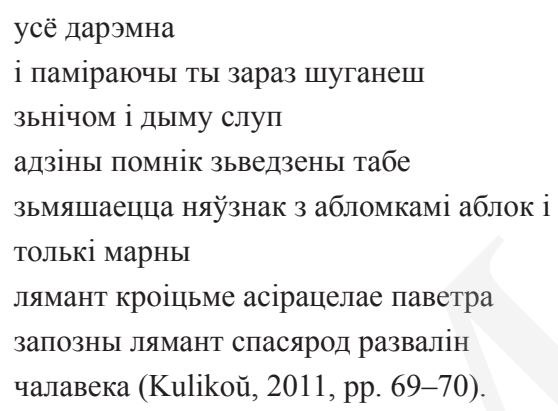

Another prose poem, rather expansive and certainly more personal, though in many ways even more bleak, is U pierapiskach nasielnictva, nia kažučy - u history, ciabie niama... (In the correspondence of the population, not to mention history, you do not exist...):

У перапісках насельніцтва, ня кажучы - у гісторыі, цябе няма. Ты не здаваў аналізаў, не наведваў экспертызаў. I калі да цябе дазваніліся, ты дзейнічаў, як дзейнічаў бы Фама: адключыў тэлэфон, зашморгнуў фіранкі, схаваўся ў старой валізе.

У школе ты дрэнна вучыўся - выдатна іграў на нэрвах. Зімою скрыпеў на зубох і вока мазоліў з прыходам вясны. На ўроках ты моўчкі сядзеў пад партай, ня гоцкаў ні 3 кім на пярэрвах, а ў адзінаццатым рэзка зьнік, забіўшы на выпускны.

Казалі, што ты разумова адсталы і доўга не пражывеш, што сядзеш на голку, ў турму або, ня дай божа, паткнесься ў баптыстыя. Але насамрэч цікавіў ты іх не болей, чым нейкі там Банглядэш, Зымбабвэ, родная мова, гомасэксуалістыя.

Ты быў ім патрэбен як нуль у сыстэме сваіх ацэнак, пустое месца, на тле якога значацца лініі іх жыцьця. Па-свойму ўнікальныя, homo sapiens у вывіхнутым калене, яны часта глядзеліся ў люстра - што дзіўна для сьлепакоў. Хаця...

I ты злаўчыўся не давяраць прасторы, тым больш - сваё другое <я>. Трымаў яго ў сакрэце, за кубкам кавы, ў дыме цыгарэты. Ты не даваў яму прарвацца вонкі, на кончык языка, натрэснуць голас твой і зьнікнуць за мяжою нутранога сьвету. 
Няроўнасьць, думаў ты, павінна... вучыць нас дабрыні й любові, і толькі так магчыма апраўдаць яе прысутнасць у быцьці. Само ж быцьцё нам дадзена адно змагацца: 3 формай, з словам, з самім сабой, - набрыньваючы Богам, які - у небыцьці.

Яны ня вытрывалі доўга тваёй адсутнасьці - і выдалі дэкрэт: павесіць табе бразготку, не раўнуючы на карову, выкачаць цела ў фосфары й выдзяліць 3 космасу бачны сьлед. І ты б з усім пагадзіўся, але ў сама апошні момант - заняў сабе мову (Kulikoŭ, 2011, pp. 25-26).

Perhaps this prose poem stretches the limits of lyrical miniatures too far, but it is the nearest that Kulikoŭ comes to that genre. It is remarkable for its free use of slang, and the reference to the dismissal of the language by many of his philistine compatriots gains particular resonance in view of his second book, Svamova (the title is untranslatable) in which he attempts to create his own 'pure' language that is rich but sometimes obscure (Kulikoŭ, 2013). Also worth mentioning is his most recent book of poems, Sivier-Hara: Vieršy (Silver Mountain: Poems), which comprises poems written in 2013-15, where the importance of language is prominent from the first page (Kulikoŭ, 2015).

Talented bard and poet Viktar Siamaška (b. 1980) is a Catholic, and many of his poems reflect this, although he also makes many bold political statements. The religious poems are not conventional, and his $\mathrm{Na}$ vialiki post (On Lent) portrays the emptiness of worldly life in the face of outraged angels and death. It may serve as an example of lyrical miniatures, beginning with a short unrhymed poem followed by a prose passage and ending with a well-known sentiment found in the Committal from the Book of Common Prayer, 'earth to earth, ashes to ashes, dust to dust':

\section{На Вялікі Пост}

Абразы пазіраюць з абразай

Адгукаюцца крокі ў карку

Мірыям пакідае горыч

Мірыям зьнішчае гонар

Поўня поіць

Малаком апоўначы

У цемры ня бачна бруду

Толькі ксёндз з клярнэтам

Ці адчуваў ты сябе калі-небудзь болей спустошаным, чым зараз? Ці адчуваў першародны суіцыдальны інстынкт? Ты хочаш ціхага самотнага жыцьия, хочам спаць і есьйі, і пісаиь штосьиі киталту гэтага. Але не выпадае. Усе твае уяўленьні й перакананьні сталіся прыдумкаю. Выпрацаваныя табой законы й мэтады не 
спраиоўваючь. Дарэмна штосьиі прагназавачь. Ты не разумееш, як успрымаиь сваё існаваньне. Толькі словы. Толькі размытыя фарбы... А як прыемна икадаващь сябе! Пазьбягащь любое напругі! Колькі вакол задавальненьняў! Колькі чікавых заняткай, паездак, сустрэчай!.

„Памятай, ты прах і прахам станеш” (Siamaška, 2013, p. 62).

A far more humorous view of death is shown in the miniatures by a writer so far best known as a poet, Usievalad Ścieburaka (b. 1981), Roznyja śmierci (Various deaths) and Linija liosu (The line of fate). His verse and prose is notable for its clarity, without the complexity that attracts some young writers, composers of music who consciously avoid tunes or even themes. Ścieburaka's prose poems about life and death bring not only an element of humour but also modernity to an eternal theme. Here is the first of them:

Розныя сьмерці

Адкуль такі стэрэатып, што сьмерць старая жанчына 3 касой?

Я мяркую, што сьмерць мае тыя выгляд і век, якія мае яе ахвяра. То бок, калі ты сам бяззубая старэча - і сьмерць твая адпаведна - бабуля з устаўной сківіцаю. Калі ты малады - то і сьмерць, што прыходзіць да цябе - прывабная паненка. Па малых наогул прыходзіць дзяўчынка са стужачкай у валасах... (Ścieburaka, 2013, p. 94).

Somewhat longer and broader in scope is the same author's Linija liosu (The line of fate), which introduces multiple and diverse, sometimes very specific, metaphors to help the reader understand the human life span:

\section{Лінія лёсу}

Жыцьцё бывае доўгае, бывае кароткае. Здараецца, што людзі думаюць пра сваё жыцьцё занадта добра, а само яно гэтак ня лічыць. Найперш разыходжаньні праяўляюцца ў тым, наколькі працяглым гэтае самае жыцьцё будзе.

На маёй руцэ лінія жыцьця неверагодна доўгая. На яе руцэ - дзіўна кароткая.

Але.

Трэба мець на ўвазе, што і ў выпадку, нібы прадвызначаным лёсам і пацьверджаным прыродай, ня ўсё гэтак проста. У Windows Media Player ва ўсіх трэках, як відэа, гэтак i аўдыа, даўжыня дарожкі на застаўцы заўсёды аднолькавая. Пры гэтым працягласьць аднае песьні 6 хвілінаў, а іншай - 2. Па адной індыкатар рухаецца ледзь-ледзь, па іншай ляціць. Заўважылі?

Дык вось, на маёй левай далоні дарожка жыцьця доўгая, але хуткасьць яе прайграваньня вялікая. Таму і скончыцца яна можа значна раней, чымсьці падаецца. Усім дадзены аднолькавы па памеры кавалак існаваньня, і нехта яго прабягае, як спрынтр свае 100 
метраў, а хтосьці прапаўзае па-пластунску і яшчэ спыняецца адпачыць. Цяжка сказаць, які рух прыносіць больш задавальненьня. Можа быць, што абодва маюць нечакана хуткае заканчэньне, бо на руцэ не адзначаецца бегунком, як на прайгравальніку, шлях, што ўжо застаўся за плячыма (Ścieburaka, 2007, p. 104).

Adam Šostak, a performance artist and poet, also includes some prose in his first book, and, as has been mentioned, calls two examples of them poems in prose, Virtuainaje: fotarobat (Virtual: a photo robot, 2004) and Kazka ŭ liusterku (A fairy tale in the mirror, 2005). The first concerns the lyrical hero's frustration at the elusiveness of his girlfriend, despite many attempts to contact her electronically; thinking of calling Interpol, he realizes that her distinguishing mark, an appendix scar, will not be apparent to them. The second, also intimate, has a more mysterious yet broader philosophical theme:

Казка у люстэрку

Побач ішлі людзі. Іх была цэлая процьма - рознакаляровых вясёлак.

- Што адбываецца ў тваім свеце? - спытала дзяўчынка пяшчотна. - У крывым люстэрку я распавяду табе сваю казку. Табе першаму стрэчнаму... Толькі пакінь, калі ласка, сваё люстра... Толькі выйдзі з люстраное шафы... Ты будзеш ведаць, у свеце хто лепшы вандроўнік...

Верагодна, а магчыма і дакладна сапсуецца надвор'е: снежнымі позіркамі, няўдалай вясною... «Не прытуляйцеся да шкла» - распластавана паверхня надпісам у шыбе. Бо гэта не шкло, а люстэрка 3 дакладным свету адлюстраваннем асветленых мараў, дзе аварыйнае выйсце з надзвычайнай сітуацыі. Сітуацыйна спяваюць невядомыя птушкі, у іншы дом прыляцеўшы, сумныя казкі шырокафарматных экранаў.

А побач ішлі людзі. Ад мыльнай оперы да меладрамы. Іх была цэлая процьма; і ты не адчуеш нават у словах ix, што патаемнага хаваецца ў кожным сэрцы (Šostak, 2006, p. 90).

Far from fairy tales of any kind is Anka Upala, a witty poet and writer with a strong satirical bent. In the example of her miniature prose works that follows, Matryjarchi i patryjarchi (Matriarchs and patriarchs) the theme is entirely modern: different makes of mobile phones:

\section{Матрыярхі і патрыярхі}

Нават цяпер пераход на мабільны тэлефон іншага брэнда выклікае пэўныя часовыя нязручнасці: трэба прызвычаіцца да таго, што не так змешчаны кнопкі, іншым чынам арганізаванае меню...

Думаю з цягам часу чалавек ад нараджэння будзе замацоўвацца за якім-небудзь вытворцам тэхнікі. Калі прыстасаванні ўскладняцца, лягчэй будзе ўдасканаліць сябе новай мадэллю звыклай кампаніi, чым ламаць сваю свядомасць і жыццё зменай брэнда. 
Таму да сямейных прозвішчаў будуць дадаваць назву кампаніі-вытворцы, прадуктамі якой карыстаецца сямейства: Кавалёвы-«Атлант» (гэта будзе рэдкае прозвішча прыхільнікаў айчыннага вытворцы). Кузьміч-«Самсунг»... Не выключана, што і рэкламны слоган кампаніi будзе пазначацца ў пашпарце: «Canon - You Can! Ты можаш, Казлоў!».

Прадстаўнікі аднаго брэнда будуць знаходзіць паміж сабой больш агульнага і жаніцца будуць часцей таксама адно з адным. Такім чынам, усе мы можам стаць матрыярхамі і патрыярхамі, ад якіх будуць выводзіць свой радавод сем'i-брэнды (Upala, 2012, pp. 73-75).

Almost all the writers whose works are cited above also wrote in verse. Some, however, of those whose miniatures are to be quoted below appear to have been part of a trend or tendency to write short, often lyrical, prose, particularly in the journal "Maladość", in the late $20^{\text {th }}$ and early $21^{\text {st }}$ centuries. Some of these young writers appear to have produced only one or two miniatures and it is not possible to quote or even mention most of them. One writer, however, who has published several pieces in this genre is Ihar Prakof'jeŭ, a journal correspondent who was born in Russia in 1975 but who has lived in Slonim since 1987; he calls his short prose alternately minijaciury and abrazki; Babina zima (Granny's winter) is one of his more lyrical, even sentimental miniatures:

\section{Бабіна зіма}

Бабіна лета у вёсць - сапраўднае свята. Свята гукаў, фарбаў і пахаў. Канец лета баба Люба сустракала з асаблівым хваляваннем і захапленнем. У гэтыя восеньскія дні яна заўсёды рабіла варэнне па ўласным рэцепце. Не, не для суседзяў ці якіх-небудзь гасцей, а... для мух. У верасні вясковыя мухі надзіва тлустыя і ўкормленыя, амаль як хрушчы, таму для іх баба Люба засцілала стол белым абрусам, разлівала пачастунак у кубкі і сподкі, адчыняла ўсе дзверы і вокны, а сама ішла гаспадарыць на агарод. Мухі радасна гудзелі, заляталі ў хату, сядалі за стол - прымаліся за варэнне. Пачаставаўшыся, адны мухі засыналі, а іншыя, наадварот, пачыналі гойсаць па хаце і траплялі ў павучыныя пасткі.Тры дні баба Люба збірала мух па ўсёй хаце, а на чацвёрты казала: $<$ Калі мухі не ляцаць да павуціны, дык няхай павуціна ляціць да мух>, і адпускала павуцінкі на волю. Маленькія сеткі хутка вярталіся са здабычай дахаты. Усіх злоўленых мух баба Люба замочвала ў спецыяльным настоі ў дзежцы, якую ставіла ў цёмны склеп, дзе так знаходзілася да самых Каляд.

Калі на навагоднія святы ў госці да бабы Любы прыяджалі дзеці з унучкамі, гаспадыня даставала мух з настою і клала насякомых сушыцца на печ. Мухі ажывалі, рабіліся рознакаляровымі і бліскучымі, як лямпачкі на электрычнай гірляндзе, і $з$ шумам саскоквалі ў сярэбраны куфэрак.

У ноч пад Новы год баба Люба разам з дзецьмі і ўнукамі ішла на надворак, дзе расла цудоўная прыгажуня елка. Унукі адчынялі куфэрак. Мухі выляталі, садзіліся на елку, якая ад гэтага пачынала мільгацець тысячамі жывых агеньчыкаў. А на вершаліне за- 
мацоўвалі яркую чырвоную зорку, каб Дзед Мароз і Снягурка здалёк убачылі яе і не мінулі падворак бабы Любы. Бліжэй да ночы прыходзілі суседзі, дарылі падарукі, спявалі, скакалі і вадзілі святочны карагод вакол елкі.

Роўна ў поўнач, калі па тэлевізары званілі куранты, пад страхой бабінай хаты, на гарышчы, нараджаўся хлопчык Новы Год. Ён рос не па днях і нават не па гадзінах, а па хвілінах, і па драўлянай лесвіцы жвавенька збягаў уніз да святочнага стала. Госці атрымлівалі з рук бабы Любы па кавалку навагодняга пірага са свечкай. На чароўнай паперы кожны пісаў свае самыя запаветныя мары, і каб яны збыліся, спальваў паперку ў полымі свечкі, раствараў попел у шампанскім і выпіваў напой да дна.

$<$ Жадаю, каб радасць і шчасце не канчаліся ніколі, і ў людзей хапіла розуму іх зберагаць і ўратаваць>, такія словы прачытаў калядны агонь у адной маленькай паперцы. Гэта было запаветнае жаданне немаўляткі Новага Года (Prakof'jeŭ, 2007, pp. 26-27).

Voliha Kolas (b. 1980) is the author of a cycle of miniatures under the title Śniežnyja napievy (Snowy melodies), one example of which is the second of three with the subtitle, Abločnaja para (Cloudy weather):

Блакітныя пералівы расчаравання змяшаліся з ружовымі надзеямі. У самым версе вячэрняй журбы трапеча белы месяц, прыбіты цяжкім цвіком. Хутка ён акругліцца ва ўладарную поўню, якая рассыпле па зямлі лёгкую пудру вечнасці, і кожны прыпыніцца, задумаецца над лёсам і хуткаплынным жыццём. На захадзе неба светла-жоўтае. Яго казачна адцяняюць голыя дрэвы, на якіх, як апошнія засохлыя лісты, нерухома сядзіць маўклівая чарада чорных птушак (Kolas, 1997, p. 12).

Voĺha Lis, in an abrazok called Biaroza (The birch tree), begins by hymning the beauties of spring, before describing how a man with a saw cuts down the eponymous tree. At the end of her piece this reckless behaviour broadens into a reflection on life as a whole:

Напэўна, можна правесці паралель паміж нашым жыццём і гэтым выпадкам. Бо той чалавек, як і ў большасці мы ўсе, забыў сваю гісторыю: можа, пад гэтай бярозай прызнаваўся ў каханні яго дзед або хаваўся ў спёку бацька...

Але гукі робяцца усё мацнейшымі, і вось, нарэшце, мужчына 3 палёгкай уздыхае, бо з трэскам падае здаровая крона, пляскае аб асфальт пазелянелае голле.

І з абрэзанага ствала капае салодкі бярозавы сок, але цяпер ён больш нагадвае слёзы, слёзы роспачы і адчаю, якія высыхаюць пад ласкавым красавіцкім сонцам... (Lis, 2002, p. 11).

Siarhiej Salonienka begins a small cycle of miniatures with another story Biarozka (The little birch tree) about cutting down a silver birch tree, although its stump still provides refreshment for some insects and birds. Here are the closing lines: “А бярозавы пянёк насуперак усяму поіць сваім жывым сокам сасмяглых. А ці жыву я так, каб пакінуць пасля сябе хоць бы кроплю жыватворнай вільгаці?” (Salonienka, 2007, p. 87). 
In another miniature, Niezabudka (Forget-me-not), Salonienka reflects on the changes of the seasons and wonders whether the forget-me-not exists to remind humans of the impermanence of joy and satisfaction:

\section{Незабудка}

У лесе буяе май. I ў вачах рабаціць ад яркіх колераў, нібы глядзіш у калейдаскоп. Дрэвы адзеліся ў свежых смарагдава-сакавітыя сукенкі: сонечнымі асколкамі блішчаць дзьмухаўцы. Далікатныя ліхтарыкі ландышаў, нягледзячы на сваю мініяцюрнасць, асляпяльна ззяюць. I ў хвалях гэтай прыгажосці аб нечым нявыказана таямнічным і прыемным складаюць свае песні салаўі. Як цудоўна пасля чорна-белай зімовай нудоты любавацца майскімі краявідамі! Хочацца глядзець на зямлю не адрываючыся. Раптам вочы натыкаюцца на маленькія нябесна-блакітныя кропелькі. Незабудкі. І я ўспамінаю, што над квітнеючай майскай зямлёй раскінуўся блакіт неба. Завянуць кветкі, змоўкнуць птушкі, выгарыць, пажоўкне і ападзе лісце, зямля зноў стане чорна-белай, і толькі неба застанецца блакітным. У міг зямной радасці мы нярэдка забываем, што яна вельмі хутка міне. А вечная асалода толькі ў нябёсах. Можа, для таго, каб мы не забывалі пра гэта, і цвіце незабудка (Salonienka, 2007, p. 89).

A comparable reflection is put in a considerably more prosaic way by Śviatlana Kostrykava in her abrazok, Ich raskrytyja dušy (Their revealed souls):

Іх раскрытыя душы

Рука моцна абдымае акруглыя формы кубка, вусны лёгка дакранаюцца яго краёў - адчуваю, як цяпло духмянага чаю плыве ўнутры мяне. А вочы хітра сочаць за горкай цукерак, што ляжаць насупраць. Мабыць, першы раз у жыцці я так задаволена тым, што я чалавек, што маю дзве рукі. Вось мая другая памочніца цягнецца па чарговую цукерку. Падымаю вочы: на стале ўжо шмат разадраных цукерачных абгортак. Я бачу іх раскрытыя душы. Яны такія сумныя, бо страцілі сваё «сэрца», сваю палавіну, упрыгожаннем якой з'яўляліся да таго часу, пакуль мая прагная рука з вясёлым запалам не пачала тармасіць прыгожыя паперкі.

Вось і апошняя з іх легла на стол.

Адчуваю, што ў поўнай меры атрымала неабсяжную асалоду. Але якой цаной... Дзеля чаго. Каб самой атрымаць хвіліны задавальнення, я парушыла гармонію, спалучэнне карыснага $з$ прыгожым.

А хіба такое не здараецца ў чалавечым жыцці? У выніку адчайнай барацьбы за задавальненне сваіх патрэб і капрызаў часта даводзіцца пераступаць праз многае, праз многіх. І ў такія хвіліны чамусьці не думаеш, ці добра ты робіш, ці не. Да мэты - любой цаной! А калі азірнешся назад, бачыш і разумееш: ужо позна... (Kostrykava, 2005, pp. 11-12). 
One of the youngest of the writers from "Maladość" to be mentioned here is Aliona Rulievič whose work is described, probably by the editors, as mini-prose. In Vosieński viečar u horadzie (An autumn evening in the city), she sketches a picture of the incomprehensible lights and sounds of this mysterious time:

\section{Восеньскі вечар у горадзе}

Дагарала свечка яснага дня. Ужо вечар шэрай птушкай блукаў між складанай сеткі бясконцых дарог, электрычных правадоў, змораных тралейбусаў, тужлівых чалавечых вачэй.

Стары, агрубелы ліст, нібы тлеючы вугалёк, хапаў паветра, абняўшы назаўсёды зямлю. Ён паміраў і ўжо не заўважаў, што халоднае неба хавае між зор карагод такіх жа сухіх анямелых душаў, якія пакінулі целы бяроз, клёнаў, каштанаў... Восень шукала прытулку. І ніяк не знаходзіла...

Ліхтары начнога горада, нібы восеньскае сонца, лілі на зямлю халоднае святло, але не сагравалі. Колкі вецер завісаў на павуцінках, шаптаў павукам казкі на ноч. Але ўсё ж восень больш маўчала. А людзі на аўтобусных прыпынках, на вуліцах, у кватэрах усё слухалі і слухалі яе таямнічую цішыню. Хацелі зразумець гэты загадкавы восеньскі вечар. Дарэмна... (Rulievič, 2004, p. 29).

The unusual genre of one of Taciana Andruška's miniatures is in its title, Prypavieść (Parable). It compares specs of stars in the universe appearing to be seeking to join together like the way humans do, in an equally difficult and senselessly random way (Andruška, 2004, p. 65). The genre of this piece, written five years after Vasiĺ Bykaŭ's Pachadžanie (Prypavieści) (The Pilgrims [Parables]) (Bykaŭ, 1999), may cast doubt on the assertion made at the beginning about this great writer's heritage, although it appears to be no more than a single case.

Vasil Šyjonak, in his 'urban abrazok', $U$ abdymkach adzinoty (In the embrace of loneliness), describes the contrast between a bracing winter day and the sadness of some of the life beyond the narrator's world, notably a cat that has been turned out after the death of its loving owner and which wanders along the pavement but suddenly imagining a break in the stream of vehicles, like Moses parting the waters, slowly attempts to cross the road but is run over by a huge lorry (Šyjonak, 2005, pp. 7-8).

To conclude, the fate of lyrical miniatures, made his own by Janka Bryl in the second half of the $20^{\text {th }}$ century, has not been as abrupt and tragic as that of the cat in the last example cited here. What, however, the father of the genre would have thought of some of the texts quoted above must remain unknown, but he certainly belonged to his own generation, and in Belarus, for all its conservatism, the $21^{\text {st }}$ century has, in literary terms at least, clearly distinguished itself from the preceding era. 


\section{Bibliografia}

\section{Źródła}

Andruška, Taćciana. (2004). Prypavieść. Maladość, 9, p. 65.

Bajarovič Źmitrok. (2012). Šali. Miensk: Halijafy.

Biadulia, Źmitrok. (1913). Abrazki. St. Petersburg: Zahlianie sonca i ŭ naša vakonca.

Bykaŭ, Vasiĺ. (1999). Pachadžanie (Prypavieści). Vilnius: Vostraja brama.

Dubaviec, Siarhiej. (1992). Praktykavańni. Miensk: Mastackaja litaratura.

Halubovič, Lieanid. (1998). Zaciemki z lievaj kišeni. Miensk: BHAKC.

Harecki, Maksim. (1993). Skarby žyćcia: Viečnaje polie pamiaci. Polymia, 2, pp. 3-138.

Janovič, Sakrat. (1984). Miniatures. Translated by Shirin Akiner. London: The Anglo-Belarusian Society.

Jemial'janaŭ-Šylovič, Aleś. (2013). Parasoniečnaść. Miensk: Knihazbor.

Jemial'janaŭ-Šylovič, Aleś. (2014).Teliepaetyka. Dziejasloŭ, 71 (4), pp. 57-62.

Kolas, Voliha. (1997). Abločnaja para. Maladość, 5, p. 5.

Kostrykava, Śviatlana. (2005). Ich raskrytyja dušy. Maladość, 2, pp. 11-12.

Kulikoŭ, Ihar. (2011). Pavarot na mora. Miensk: n.p.

Kulikoŭ, Ihar. (2013). Svamova. Miensk: Medisont.

Kulikoŭ, Ihar. (2015). Sivier-Hara. Miensk: Medisont.

Lis, Voĺha. (2002). Biaroza. Maladość, 2, p. 11.

Martysievič, Maryja. (2008). Cmoki liatuć na nierast. Miensk: Lohvinaŭ.

Prakof'jeŭ, Ihar. (2007). Babina zima. Maladość, 9, pp. 26-27.

Razanaŭ, Aleś. (1995). Paliavańnie ŭ rajskaj dalinie. Miensk: Mastackaja litaratura.

Rulieva, Aliona. (2004). Vosieński viečar u horadzie. Maladość, 4, p. 29.

Salonienka, Siarhiej. (2007). Biarozka. Maladość, 7, p. 87.

Salonienka, Siarhiej. (2007). Niezabudka. Maladość, 7, p. 89.

Siamaška, Viktar. (2013). Habitacyja. Miensk: Halijafy.

Ścieburaka, Usievalad. (2007). Krušnia, Miensk: Viktar Chursik.

Ścieburaka, Usievalad. (2013). Bieh pa samaadčuvańni. Miensk: Halijafy.

Šostak, Adam. (2006). Spatkańnie, Nie. Miensk: BielSaES ‘Čarnobyl'.

Šyjonak, Vasiĺ. (2005). 'U abdymkach adzinoty’. Maladość, 2, pp. 7-8.

Upala, Anka. (2012). Dreva Entalipt. Miensk: Lohvinaŭ.

\section{Opracowania}

Dasajeva, Tacciana. (2001). Paetyka liryzmu ŭ bielaruskaj prozie. Miensk: BDU.

Kiślicyna, Hanna. (2000). Liryčnaja minijaciura jak žanr bielaruskaj litaratury. Miensk: Bielaruskaja navuka.

McMillin, Arnold. (2015). Spring Shoots: Young Belarusian Poets in the Early Twenty-First Century. London: The Modern Humanities Research Association.

Miščančuk, Mikoła. (2007). Liryčnaja proza jak fienaminaĺnaja z'java ŭ litaratury XX stahodździa. Miensk: Bielaruskaja navuka. 


\section{Summary}

This article considers the genre of prose lyrical miniatures, which Janka Bryl had made his own, in the work of young Belarusian writers. The material is based on those who began as poets, and those who followed what seems to have been a trend in "Maladość" at the turn of the century. These youthful works are notable for their thematic variety, and not all are lyrical in a way that Bryl would have recognized, but they affirm the genre's durability.

Key words: contemporary, Belarusian, lyricism, miniatures, heritage, variety, fashion

\section{Streszczenie}

Mistrzem miniatury w okresie radzieckim był Janka Bryl. W niniejszym artykule poddano analizie genologicznej miniatury lirycznej w prozie młodych pisarzy białoruskich. Materiał badawczy stanowiły prace pisarzy, którzy rozpoczynali karierę literacką jako poeci, a także teksty autorów sięgających po tę form1) i publikujących teksty na łamach czasopisma „Maładość" na przełomie wieków. Nie wszystkie liryczne miniatury są „liryczne” w rozumieniu Janki Bryla, jednak właśnie ich różnorodność świadczy o żywotności tego oryginalnego gatunku.

Słowa kluczowe: współczesny, białoruski, liryczność, miniatury, spuścizna, moda

\section{Рэзюме}

У дадзеным артыкуле разглядаецца і аналізуецца жанр, майстрам якога ў савецкі перыяд з'яўляўся Янка Брыль, празаічнай лірычнай мініяцюры ў творах маладых беларускіх літаратараў. Матэрыял артыкула складаюць працы тых, хто распачынаў літаратурную кар'еру як паэт, а таксама пісьменнікаў, якія прытрымліваліся тэндэнцыі гэтага жанру, што прасочваецца ў часопісе “Маладось” на мяжы стагоддзяў. Не ўсе лірычныя мініяцюры “лірычныя” ў тым сэнсе, як гэта разумеў Янка Брыль, але менавіта іх разнастайнасць даказвае жывучасць гэтага арыгінальнага жанру.

Ключавыя словы: сучасны, беларускі, лірызм, мініяцюры, спадчына, мода 